\title{
Congenital Deformity of Hip
}

National Cancer Institute

\section{Source}

National Cancer Institute. Congenital Deformity of Hip. NCI Thesaurus. Code C34881.

Any anatomic abnormality of the hip that is present at the time of birth. 